\title{
Large-diameter trees dominate snag and surface biomass following reintroduced fire
}

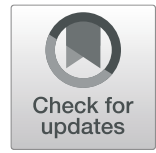

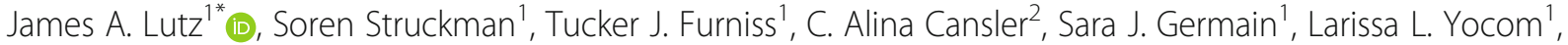 \\ Darren J. McAvoy ${ }^{1}$, Crystal A. Kolden ${ }^{3}$, Alistair M. S. Smith ${ }^{4}$, Mark E. Swanson ${ }^{5}$ and Andrew J. Larson ${ }^{6}$
}

\begin{abstract}
The reintroduction of fire to landscapes where it was once common is considered a priority to restore historical forest dynamics, including reducing tree density and decreasing levels of woody biomass on the forest floor. However, reintroducing fire causes tree mortality that can have unintended ecological outcomes related to woody biomass, with potential impacts to fuel accumulation, carbon sequestration, subsequent fire severity, and forest management. In this study, we examine the interplay between fire and carbon dynamics by asking how reintroduced fire impacts fuel accumulation, carbon sequestration, and subsequent fire severity potential. Beginning pre-fire, and continuing 6 years post-fire, we tracked all live, dead, and fallen trees $\geq 1 \mathrm{~cm}$ in diameter and mapped all pieces of deadwood (downed woody debris) originating from tree boles $\geq 10 \mathrm{~cm}$ diameter and $\geq 1 \mathrm{~m}$ in length in 25.6 ha of an Abies concolor/Pinus lambertiana forest in the central Sierra Nevada, California, USA. We also tracked surface fuels along $2240 \mathrm{~m}$ of planar transects pre-fire, immediately post-fire, and 6 years post-fire. Six years after moderate-severity fire, deadwood $\geq 10 \mathrm{~cm}$ diameter was $73 \mathrm{Mg} \mathrm{ha}^{-1}$, comprised of $32 \mathrm{Mg} \mathrm{ha}^{-1}$ that persisted through fire and $41 \mathrm{Mg} \mathrm{ha}^{-1}$ of newly fallen wood (compared to $72 \mathrm{Mg} \mathrm{ha}^{-1}$ pre-fire). Woody surface fuel loading was spatially heterogeneous, with mass varying almost four orders of magnitude at the scale of $20 \mathrm{~m} \times 20 \mathrm{~m}$ quadrats (minimum, $0.1 \mathrm{Mg} \mathrm{ha}^{-1}$; mean, $73 \mathrm{Mg} \mathrm{ha}^{-1}$; maximum, $497 \mathrm{Mg} \mathrm{ha}^{-1}$ ). Wood from large-diameter trees $(\geq$ $60 \mathrm{~cm}$ diameter) comprised $57 \%$ of surface fuel in 2019, but was $75 \%$ of snag biomass, indicating high contributions to current and future fuel loading. Reintroduction of fire does not consume all large-diameter fuel and generates high levels of surface fuels $\geq 10 \mathrm{~cm}$ diameter within 6 years. Repeated fires are needed to reduce surface fuel loading.
\end{abstract}

Keywords: California Rim Fire, Fuel reduction, Sierra Nevada mixed-conifer, Smithsonian ForestGEO, Yosemite Forest Dynamics Plot, Yosemite National Park

\section{Introduction}

Reducing woody biomass fuel loads through reintroduction of fire is seen as an important step to decreasing future fire risk and increasing forest resilience in many ecosystems of western North America (Larson et al. 2013, Hessburg et al. 2015, Valliant et al. 2016). Forests where fire was once frequent have been reported to have higher tree densities, particularly of smaller and medium trees,

\footnotetext{
*Correspondence: james.lutz@usu.edu

'Department of Wildland Resources, S. J. and Jessie E. Quinney College of Natural Resources, Utah State University, 5230 Old Main Hill, Logan, Utah 84322-5230, USA

Full list of author information is available at the end of the article
}

than was common prior to the 20th century (i.e., Becker and Lutz 2016, Levine et al. 2017, 2019). Although fireinduced mortality of smaller trees may be a desired outcome of reintroduced fire, one unintended consequence is the mortality of a relatively high proportion of smaller trees in addition to the medium and large-diameter trees surviving initial fire damage but succumbing to delayed fire effects (Furniss et al. 2019, 2020a). Because fire rarely consumes the boles of live trees, this pulse of delayed mortality can increase post-fire fuel levels by inputting additional biomass to snag and deadwood (down woody debris) pools (Fulé et al. 2004; Stephens 2004; Hyde et al. 
2012, Stenzel et al. 2019). Efforts to reduce these fuels through silvicultural treatment (i.e., salvage logging) have had mixed results, sometimes increasing fuel loads over the short term (i.e., Donato et al. 2006, Johnson et al. 2020a) and sometimes reducing subsequent fire severity (i.e., Povak et al. 2020).

First-entry fires following fire suppression may have substantially different impacts on forest structure, as compared to how frequent and relatively regular fires did historically (Johnstone et al. 2016). After decades without wildfire, fuel loads are higher than they would have been prior to fire exclusion, when regular fires burned surface fuels and thinned out young trees that served as ladder fuels (Harris and Taylor 2015). Consequently, first-entry fires can create patchy clumps of tree mortality (Kane et al. 2019) and higher overall fire severity compared to historical fire due to a more dense and complex fuel matrix (Harris and Taylor 2015, Kolden et al. 2017). This can give rise to distinct patterns of tree mortality (Grayson et al. 2017), post-fire demography (Varner et al. 2007), and large quantities of standing snags or deadwood pools (Miller and Urban 2000, Stephens 2004, Stephens and Moghaddas 2005, Grayson et al. 2019, Stenzel et al. 2019).

The explicit consideration of large-diameter fuels is essential because they represent a considerable portion of aboveground carbon stocks (Lutz et al. 2018a) and provide unique habitat structures that contribute to biodiversity of vertebrates and herbaceous plants (Taborska et al. 2015). Largediameter deadwood can also significantly influence future fire behavior because of the high fire intensity they generate and their burn time longevity (Thaxton and Platt 2006). While coarse woody debris accumulation following fire may be estimated using snagfall models (e.g., Vanderwel et al. 2006, Passovoy and Fulé et al. 2006) and decomposition models (Hyde et al. 2011), the generalizability of these models is severely limited by variability in snagfall rates between species, sites, and fires. Additionally, existing studies have often sampled small areas or rely on small plots $\left(1 \mathrm{~m}^{2}\right.$ to $\left.1000 \mathrm{~m}^{2}\right)$, making the examination of large diameter and long pieces of deadwood difficult (Lutz 2015). In some cases, this has led to the surprising conclusion of no post-fire increase in woody surface fuel loadings, and little deposition of large-diameter dead wood (Stalling et al. 2017).

Another challenge to quantifying impacts of reintroduced repeated fires into previously fire-excluded forests is a lack of unmanaged assessment stands, or highly characterized preand post-fire field data of the different biomass pools (Stephens 2004). Moreover, studies of large-diameter trees are generally only possible in primary forests, as secondary forests in western North America have generally not experienced enough time since harvest for significant numbers of trees to reach large diameters. Using a detailed census of trees and woody debris in a primary forest where a firstentry fire recently burned, our objective was to describe the spatial variability of pools and fluxes of snags and deadwood through time. We use this dataset to answer the following questions related to carbon dynamics of post-fire forests:

1) Following fire, what are the temporal dynamics of woody biomass pools in trees, snags, and deadwood?

2) What is the proportion of snags and deadwood represented by large-diameter trees, and how rapidly does the large-diameter surface fuel component accumulate after fire?

\section{Materials and methods \\ Description of study site}

The study took place within the Yosemite Forest Dynamics Plot (YFDP; Lutz et al. 2012, 2013) a single 25.6 ha plot located between $1774 \mathrm{~m}$ and $1911 \mathrm{~m}$ elevation in the Abies concolor/Pinus lambertiana vegetation zone in Yosemite National Park, California, USA (Yosemite) (van Wagtendonk et al. 2020, Fig. 1). The principal overstory tree species by basal area are Pinus lambertiana, Abies concolor, and Calocedrus decurrens with small populations of Pseudotsuga menziesii, Abies magnifica, and Pinus ponderosa. Important angiosperm species include Quercus kelloggii and Cornus nuttallii. Species richness of woody plants reaching $1 \mathrm{~cm}$ diameter at breast height (DBH) is 24 (see Lutz et al. 2012 for full species lists). Prior to Euro-American settlement, the fire return interval at the YFDP was 29.5 years (Barth et al. 2015) with a fire exclusion period spanning 113 years between 1899 and 2013, for a fire return interval departure of about four (Odion and Hanson 2006). Prior to EuroAmerican settlement, fires in the Abies concolor/Pinus lambertiana zone burned at mixed severities, with only small patches of high-severity fire (Scholl and Taylor 2010).

The YFDP was burned in an unmanaged backfire ignited to retard the advance of the 2013 Rim Fire (for details, see Lutz et al. 2017 for fire weather, Blomdahl et al. 2017 for unburned surface area, Cansler et al. 2019 for fuel consumption, and Stavros et al. 2016 for remote sensing data). Previous to this, the YFDP had not experienced fire since 1899 (Barth et al. 2015). Cansler et al. (2019) calculated the pre-fire coarse woody debris in the YFDP was $72 \mathrm{Mg} \mathrm{ha}^{-1}$. Fire behavior was of moderate intensity with most trees experiencing canopy and bole scorch, but few trees experiencing much canopy and bole combustion. One-year post-fire (initial) fire mortality (initial; 2014) was $71 \%$ of stems and $13 \%$ of basal area (Furniss et al. 2019, 2020a), with extended mortality (2015-2019) rising to $86 \%$ of stems and $47 \%$ of basal area (Furniss et al. 2020b). The intentional backburn ignition and the dry conditions produced fire effects in the YFDP similar to recent fires within the broader Yosemite landscape (van Wagtendonk and Lutz 2007, Lutz et al. $2009 \mathrm{~b}$ ) in contrast to the larger proportion of the unmanaged 


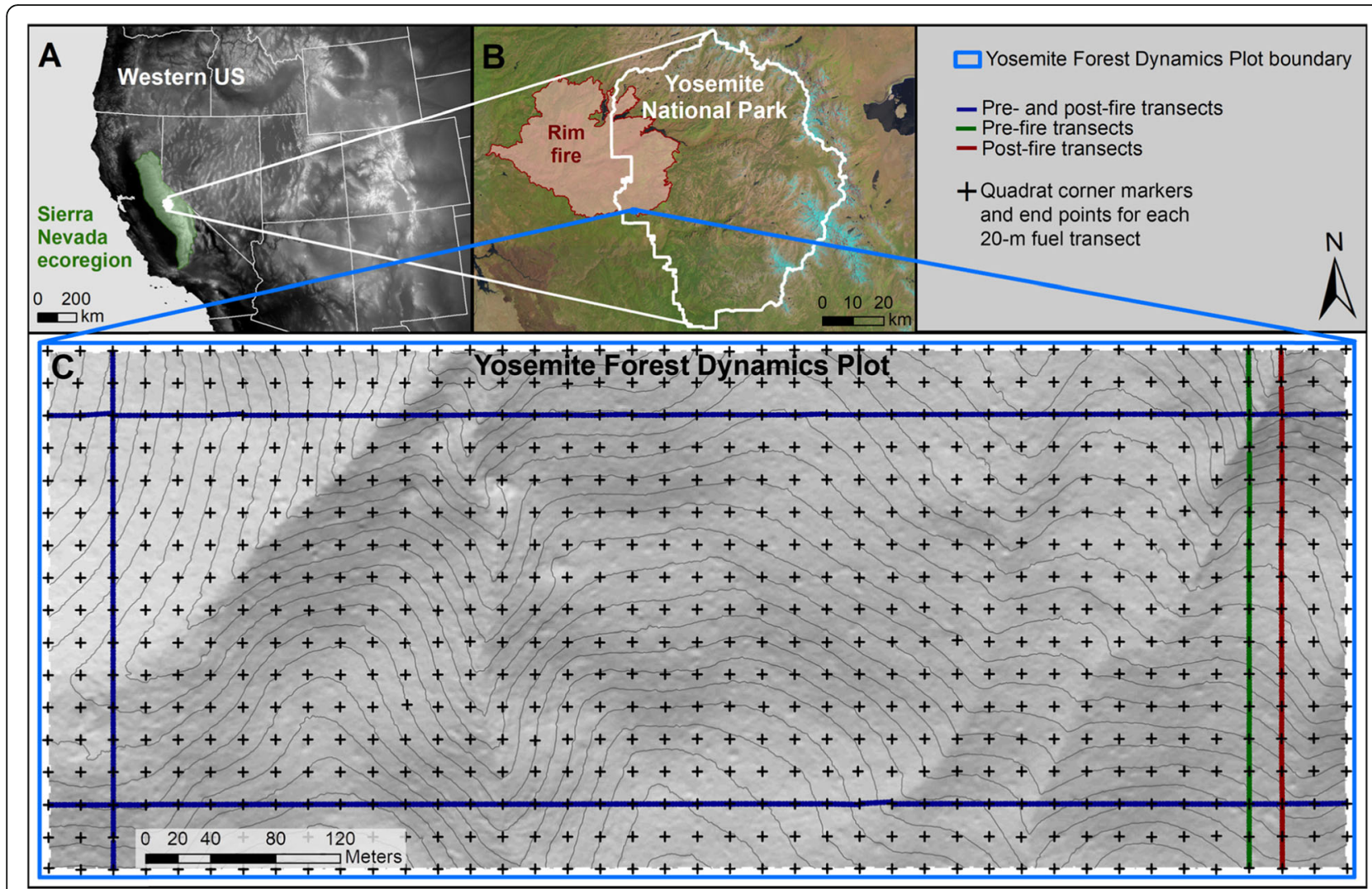

Fig. 1 The Yosemite Forest Dynamics Plot (YFDP) is located within the central Sierra Nevada (a), within the western portion of Yosemite National Park at the eastern extent of the area burned by the 2013 Rim Fire (b). The YFDP comprised 25.6 ha $(800 \mathrm{~m} \times 320 \mathrm{~m})$ surveyed as $640,20 \mathrm{~m} \times 20$ $\mathrm{m}$ quadrats (c). Explicit deadwood mapping of wood from the boles of trees $\geq 10 \mathrm{~cm}$ diameter and the location of wood from trees $1 \mathrm{~cm} \leq$ diameter $<10 \mathrm{~cm}$ was performed within the entire YFDP. Surface fuels in standard classes (litter, duff, 1-h, 10-h, 100-h, and CWD; see the "Methods" section) were measured along planar transects ("Brown's Transects") in 2011 and 2014-2019. The shaded base layer is a digital elevation model derived from 1-m resolution lidar. The eastern-most pre-fire transect (2011) was located $20 \mathrm{~m}$ west of the permanent transect points used for post-fire (2014-2019) measurements (c). Figure derived from Cansler et al. 2019; their Fig. 1

Rim Fire that burned outside Yosemite with higher-thannormal severity (Lydersen et al. 2014, Kane et al. 2015). The post-fire period coincided with a multi-year drought which increased delayed mortality (Furniss et al. 2020b).

\section{Data collection}

Within the YFDP, all trees $\geq 1 \mathrm{~cm} \mathrm{DBH}$ and all snags $\geq$ $10 \mathrm{~cm} \mathrm{DBH}$ were identified, measured, mapped, and tagged in 2009-2010 according to the protocols of the Smithsonian Forest Global Earth Observatory network (ForestGEO; Anderson-Teixeira et al. 2015, Lutz 2015). The Smithsonian ForestGEO is a global network of 70 spatially explicit plots using the same field and data protocols (Anderson-Teixeira et al. 2015). The YFDP was partitioned into $64020 \mathrm{~m} \times 20 \mathrm{~m}$ quadrats, with corners surveyed by total stations. All trees, snags, and logs in the entire 25.6 ha area were originally referenced to the surveyed grid. Subsequent to plot establishment, and prior to fire, each of the 34,866 original trees and 2735 snags in the YFDP (see Table S1 for demographic data) was visited each year (2011-2013) to check for mortality and snagfall (new recruitment was also recorded), with the 2013 survey resulting in a comprehensive stem map of pre-fire trees and snags. We remeasured the diameter of all trees and snags in 2014 and of trees again in 2019. We measured the diameter and height of each newly dead tree in every year (2011-2019).

In the year immediately following fire (2014) and the subsequent five years (2015-2019), each main bole of newly fallen stems or portions of stems (i.e., broken tops) originating from trees $\geq 10 \mathrm{~cm}$ DBH was mapped and assessed for decay class according to Smithsonian ForestGEO deadwood protocols (Janík et al. 2018). Snags and deadwood were divided into five decay classes according to the following definitions:

Class 1 -for snags; freshly dead ( $0-5$ years for many species); branches of 3rd order are present; the full height of stem is present unless there was damage prior to the mortality event or caused during the mortality event; fully barked (usually $\geq 80 \%$ of stem surface); 
usually trees that died from suppression, bark beetle outbreak (coniferous), fungal infection (broadleaved), or those killed but not burned by fire. The species is still recognizable. For deadwood; freshly fallen tree (usually windthrow or a basal rot); texture-wood intact; branches of 2nd order are attached; fully barked (usually $\geq 80 \%$ of stem surface); species is still recognizable.

Class 2-for snags; branches of the first order are present; full tree height unless there was damage prior to or during the mortality event; partly barked (usually < $80 \%$ of stem surface; broadleaved trees should be still fully barked); the species can usually still be identified. For deadwood; texture-wood intact to partly hard or soft; branches of the first order are partly attached; partly barked; the species can usually still be identified.

Class 3-for snags; only short basal rests of main branches; full height unless there was damage prior to the mortality event; bark missing or absent (usually $\leq$ $20 \%$ of stem surface) in the case of coniferous species. For deadwood; texture-wood hard but in large pieces; the wood is not compact any more along the entire stem length with the core or outer mantle subjected to rot. The genus can often be recognized, but species identification is difficult.

Class 4-for snags; no branches or small basal rests; height $\leq 80 \%$ of even height curve (according to $\mathrm{DBH}$ ); bark missing or absent (usually $\leq 20 \%$ of stem surface) in the case of coniferous species; for deadwood; texture-wood chunks small, soft, and blocky; the wood is not compact and the cross section is either elliptical or circular.

Class 5-for snags; stumps or short snags; the wood is at a stage of advanced rot. For deadwood; the wood is at a stage of advanced rot; texture-wood chunks soft and powdery; deadwood no longer has a cylindrical shape; the species cannot be identified anymore, a kick into a stem results in stem breakage.

Deadwood was tracked in two ways, depending on tree diameter. For trees $\geq 10 \mathrm{~cm}$ diameter at the previous measurement, each piece of the main bole $\geq 1 \mathrm{~m}$ long was mapped separately, and pieces shorter than 1 $\mathrm{m}$ were ocularly combined with adjacent pieces. For each piece, length and diameter at both ends were measured, as was its location (see Janík et al. 2018 for measurement details). Trees were considered to be fully "fallen" if the remaining stump height was $<1.37 \mathrm{~m}$ high; otherwise, deadwood was mapped as the "broken top" of a standing snag. Additionally, woody debris originating from main stems that was present pre-fire and persisted through the fire at a diameter $\geq 10 \mathrm{~cm}$ was mapped and assessed for decay class. For trees $1 \mathrm{~cm} \leq$ DBH $<10 \mathrm{~cm}$, the year of snagfall was recorded, but these smaller stems were not mapped and were assumed to have fallen as a single piece.

\section{Volume and biomass calculations}

The biomass of live trees was calculated using the biomass equations of Chojnacky et al. (2014). For snags that had died relatively recently (decay class 1 or 2 ) and were still intact (first-order branches present, bark intact, and top diameter $\leq 10 \mathrm{~cm}$ ), biomass was estimated with the equations of Chojnacky et al. (2014) and corrected with the species- and decay-class-specific relative density factors of Harmon et al. (2008), or if available, using the data of Cousins et al. (2015). For snags that were either in a more advanced state of decay or were not intact, their biomass was estimated by modeling their volume as a conic frustum and using the species- and decay-class-specific absolute density values provided by Harmon et al. (2008) or, if available, Cousins et al. (2015).

For individual pieces of wood on the ground, we calculated volume from their physical dimensions, assuming their shape was a conic frustum. Biomass was calculated for the entire originating tree using the equations of Chojnacky et al. (2014) and attributed to specific pieces that fell from that tree by weighting a piece according to its volume as a proportion of the total volume of the tree, including any remaining standing volume. Biomass was then corrected for decay class using the relative density factors of Harmon et al. (2008). When no values were obtainable for a species, we used values for the most closely related species with the most similar wood characteristics (i.e., specific gravity; Chojnacky et al. 2014). For pieces that could not be identified, we used an average density value calculated by proportionally weighting the identified pieces from the data set. For unknown snags, density values were $0.40 \mathrm{~g} \mathrm{~cm}^{-3}$ for decay class $1,0.35 \mathrm{~g} \mathrm{~cm}^{-3}$ for decay class $2,0.29 \mathrm{~g} \mathrm{~cm}^{-3}$ for decay class $3,0.23 \mathrm{~g} \mathrm{~cm}^{-3}$ for decay class 4 , and $0.18 \mathrm{~g} \mathrm{~cm}^{-3}$ for decay class 5 . For unknown deadwood, density values were $0.36 \mathrm{~g} \mathrm{~cm}^{-3}$ for decay class $1,0.28 \mathrm{~g} \mathrm{~cm}^{-3}$ for decay class $2,0.14 \mathrm{~g} \mathrm{~cm}^{-3}$ for decay class $3,0.14 \mathrm{~g} \mathrm{~cm}^{-3}$ for decay class 4 , and $0.13 \mathrm{~g} \mathrm{~cm}^{-3}$ for decay class 5 .

Preliminary analysis of woody debris following the 2019 remeasurement showed little change in decay class and wood dimensions in the years since fire. We therefore calculated deadwood volume and biomass in 20142019 using the values recorded when trees and snags fell into the deadwood pool. We calculated mean values of volume and biomass of deadwood for the entire YFDP and for each of the $64020 \mathrm{~m} \times 20 \mathrm{~m}$ quadrats in the YFDP. This enabled us to calculate the variability in fuel accumulation at the spatial grain of $20 \mathrm{~m} \times 20 \mathrm{~m}$. For calculating wood in each $20 \mathrm{~m} \times 20 \mathrm{~m}$ quadrat, pieces of wood that lay in multiple quadrats were split along quadrat boundaries and counted as virtual fragments that were contained within each quadrat. Pieces $\leq 10 \mathrm{~cm}$ diameter were assumed to be wholly within the quadrat that contained the rooting location of the originating tree. We also assessed the directionality of the largest 
portion of fallen trees from the deadwood endpoint locations.

In addition to the explicit mapping, we installed 2240 $\mathrm{m}$ of planar transects (Brown's transects, Fig. 1) pre-fire (2011) consisting of 112, 20-m transects (Brown 1974). Transect locations were selected to be $40 \mathrm{~m}$ from the edge of the YFDP so that trees contributing to deposition of debris would be within the YFDP (Fig. 1). We measured surface fuels in four size classes $(1 \mathrm{~h}$; less than $0.25 \mathrm{in} .(0.64 \mathrm{~cm})$ in diameter, $10 \mathrm{~h}$; between $0.25 \mathrm{in}$. and $1 \mathrm{in}$. (between $0.64 \mathrm{~cm}$ and $2.54 \mathrm{~cm}$ ) in diameter, $100 \mathrm{~h}$; 1 in. to $3 \mathrm{in}$. $(2.54 \mathrm{~cm}$ to $7.62 \mathrm{~cm})$ in diameter, and 1000 $\mathrm{h}$; greater than $3 \mathrm{in} .(7.62 \mathrm{~cm})$ in diameter) as well as litter and duff at ten points on each transect (odd meters from $1 \mathrm{~m}$ to $19 \mathrm{~m}$ ). These transects, running between the permanent quadrat markers, were resampled postfire (2014-2019). We calculated fuel loading and extrapolated to the plot scale by the methods of Brown (1974) as implemented by Cansler et al. (2019).

We calculated the time dependency of surface fuels by dividing the fallen pieces into diameter classes $(1 \mathrm{~cm} \leq$ $\mathrm{DBH}<10 \mathrm{~cm}, 10 \mathrm{~cm} \leq \mathrm{DBH}<60 \mathrm{~cm}, \geq 60 \mathrm{~cm}$, and all diameters together) and examined the fall rate from the existing years of data in terms of stems and biomass (sensu Lutz and Halpern 2006). We assessed biomass pools of live trees, portions of dead trees that were still standing, and deadwood by these diameter classes.

All calculations were performed in $\mathrm{R}$ version 3.6.2 ( $\mathrm{R}$ Core Team 2020) using packages rgdal version 1.4-8 (Bivand et al. 2019), rgeos version 0.5-2 (Bivand and Rundel 2019), sp version 1.3-2 (Pebesma and Bivand 2005), and sf version 0.8-1 (Pebesma 2018).

\section{Results}

Immediately pre-fire (May 2013), there were 34,193 trees and 4045 snags present. Of those, 408 trees and 273 snags were completely consumed by fire (no visible remains). An additional 2528 trees and 1680 snags had $\geq 75 \%$ consumption, but were still identifiable (Tables 1, S1). Fully $82 \%$ of the fire-consumed trees were $\leq 5 \mathrm{~cm} \mathrm{DBH}$; thus, they contributed minimally to consumed biomass. By 2019, there were 7069 live stems: 4853 that survived the fire and the following years of drought and 2216 net post-fire recruits (for demographic details, see Table S1). Net of consumption and snagfall, there were 13,304 remaining snags, with 20,820 trees on the ground in 2019 (Fig. 2, Table S1, Figs. S1-S8).

Table 1 Evolution of surface fuel immediately following fire (2014) and in the 5 years following in the 25.6-ha Yosemite Forest Dynamics Plot. The Rim Fire of 2013 directly consumed 12\% of trees $\leq 10 \mathrm{~cm} \mathrm{DBH}$, but very few trees $\geq 10 \mathrm{~cm} \mathrm{DBH}(0.5 \%)$. Most fire-killed trees and snags that persisted through the fire fell in subsequent years. For yearly progression of trees, snags, deadwood, recruitment, mortality, and snagfall, see Table S1

\begin{tabular}{|c|c|c|c|c|c|c|c|c|c|}
\hline & \multirow[t]{2}{*}{ Diameter class } & \multicolumn{8}{|l|}{ Year } \\
\hline & & 2014 & 2015 & 2016 & 2017 & 2018 & 2019 & Total & Per ha \\
\hline \multirow[t]{2}{*}{ Snags consumed by fire $^{\dagger}$} & $1 \mathrm{~cm} \leq \mathrm{DBH}<10 \mathrm{~cm}$ & 664 & - & - & - & - & - & 664 & 25.9 \\
\hline & $\geq 10 \mathrm{~cm} \mathrm{DBH}$ & 1289 & - & - & - & - & - & 1289 & 50.3 \\
\hline \multirow[t]{2}{*}{ Live trees consumed by fire ${ }^{\dagger}$} & $1 \mathrm{~cm} \leq \mathrm{DBH}<10 \mathrm{~cm}$ & 2863 & - & - & - & - & - & 2863 & 111.8 \\
\hline & $\geq 10 \mathrm{~cm} \mathrm{DBH}$ & 73 & - & - & - & - & - & 73 & 2.8 \\
\hline \multirow[t]{2}{*}{ Newly fallen trees and snags ${ }^{\ddagger}$} & $1 \mathrm{~cm} \leq \mathrm{DBH}<10 \mathrm{~cm}$ & 491 & 897 & 2043 & 3891 & 3468 & 3317 & 14,107 & 551.0 \\
\hline & $\geq 10 \mathrm{~cm} \mathrm{DBH}$ & 354 & 303 & 563 & 1485 & 1087 & 1481 & 5273 & 206.0 \\
\hline \multicolumn{10}{|l|}{206.0} \\
\hline \multirow[t]{3}{*}{ New pieces of deadwood* } & $1 \mathrm{~cm} \leq \mathrm{DBH}<10 \mathrm{~cm}$ & 492 & 897 & 2043 & 3894 & 3472 & 3322 & 14,120 & 551.6 \\
\hline & $\geq 10 \mathrm{~cm} \mathrm{DBH}$ & 428 & 351 & 625 & 2138 & 2218 & 2715 & 8475 & 331.0 \\
\hline & Persisted through fire & 1352 & - & - & - & - & - & 1352 & 52.8 \\
\hline \multirow[t]{4}{*}{ Deadwood volume $\left(\mathrm{m}^{3}\right)$} & $1 \mathrm{~cm} \leq \mathrm{DBH}<10 \mathrm{~cm}$ & 1.60 & 3.56 & 10.82 & 22.78 & 17.94 & 22.36 & 79.06 & 3.09 \\
\hline & $\geq 10 \mathrm{~cm} \mathrm{DBH}$ & 376.48 & 50.46 & 59.61 & 287.68 & 559.54 & 503.85 & 1837.62 & 71.78 \\
\hline & Persisted through fire & 2048.20 & - & - & - & - & - & 2048.20 & 80.01 \\
\hline & Total & 2426.28 & 54.02 & 70.43 & 310.46 & 577.48 & 526.21 & 3964.88 & 154.88 \\
\hline \multirow[t]{4}{*}{ Deadwood biomass (Mg) } & $1 \mathrm{~cm} \leq \mathrm{DBH}<10 \mathrm{~cm}$ & 0.44 & 0.96 & 2.63 & 5.82 & 4.72 & 6.03 & 20.60 & 0.80 \\
\hline & $\geq 10 \mathrm{~cm} \mathrm{DBH}$ & 276.94 & 43.00 & 37.16 & 154.83 & 253.94 & 272.03 & 1037.90 & 40.54 \\
\hline & Persisted through fire & 808.67 & - & - & - & - & - & 808.67 & 31.59 \\
\hline & Total & 1086.05 & 43.96 & 39.79 & 160.65 & 258.66 & 278.06 & 1867.17 & 72.94 \\
\hline
\end{tabular}

\footnotetext{
Less than $25 \%$ of original bole remaining in 2014
}

${ }^{\text {F}}$ Trees and snags that fell during or after fire with the remaining stump $<1.37 \mathrm{~m}$ tall

"Explicitly mapped pieces of wood $\geq 10 \mathrm{~cm}$ diameter and $\geq 1 \mathrm{~m}$ long and non-mapped pieces of wood from trees $1 \leq \mathrm{DBH} \leq 10 \mathrm{~cm}$, with those smaller trees assumed to have fallen as one piece (see the "Methods" section) 


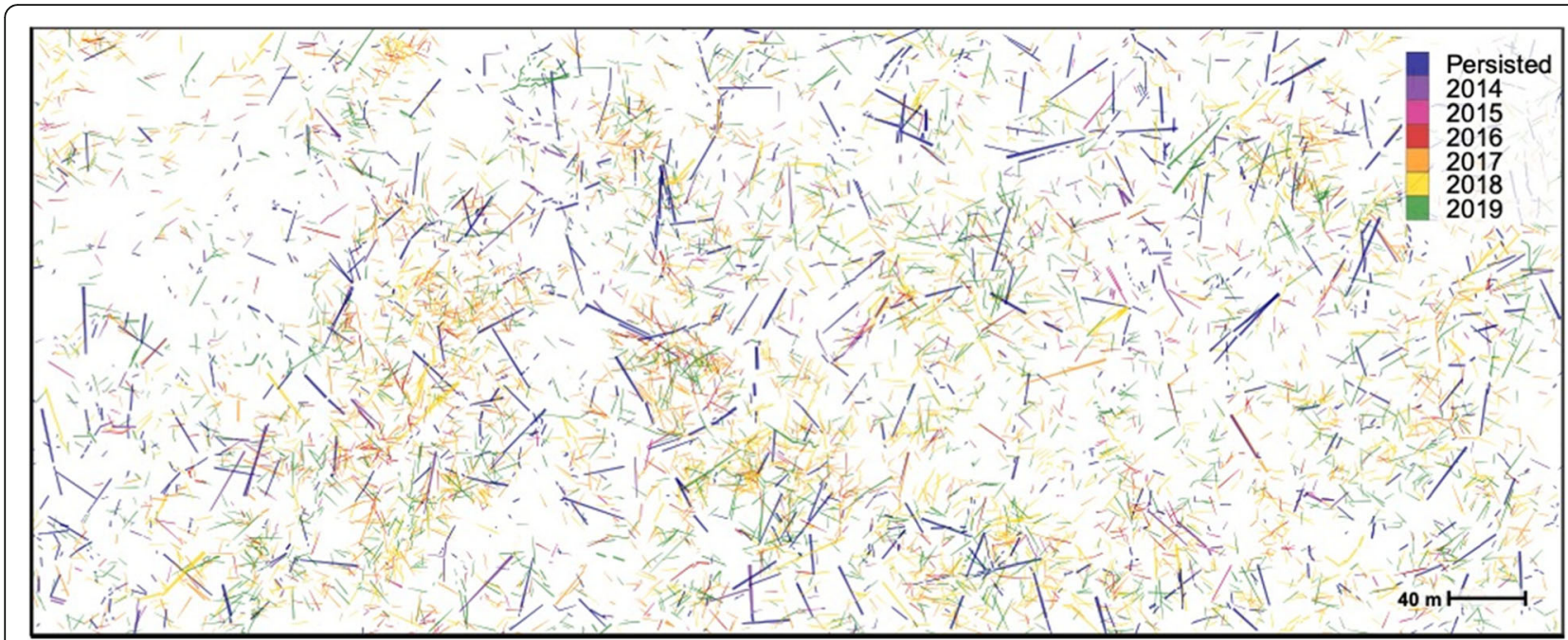

Fig. 2 The 9827 pieces of coarse woody debris $\geq 10 \mathrm{~cm}$ diameter in the 25.6-ha $(800 \mathrm{~m} \times 320 \mathrm{~m}$ ) Yosemite Forest Dynamics Plot as of 2019 showing the year of snagfall and also those pieces of deadwood that were present pre-fire and that persisted through the fire ("Persisted"). For individual figures of woody debris accumulation by species and year, see Supplemental Figures S1-S8

The accumulated wood volume and biomass (2019) in each of the $640,20 \mathrm{~m} \times 20 \mathrm{~m}$ quadrats varied by more than three orders of magnitude (Figs. 3, S9). Biomass (minimum, $0.1 \mathrm{Mg} \mathrm{ha}^{-1}$; mean, $73 \mathrm{Mg} \mathrm{ha}^{-1}$; maximum, $497 \mathrm{Mg} \mathrm{ha}^{-1}$ ), tracked volume (minimum, $0.2 \mathrm{~m}^{3} \mathrm{ha}^{-1}$; mean $153 \mathrm{~m}^{3} \mathrm{ha}^{-1}$; maximum, $1103 \mathrm{~m}^{3} \mathrm{ha}^{-1}$ ), but larger pieces generally had lower density due to their more advanced decay. Neither all deadwood nor large deadwood indicated strong directionality, but both showed slight trends in direction of fall (Fig. 4). The southwesterly bias in large deadwood reflects the direction of the Mono Wind event of 30 November 2011, which caused widespread windthrow throughout some parts of the Sierra Nevada (USFS 2012) and toppled numerous largediameter trees within the YFDP (Lutz 2015). The northeasterly bias among all trees $\geq 10 \mathrm{~cm}$ DBH is likely due to much of the YFDP having north and northeast facing aspects.

Maximum snagfall by number of trees peaked 3 years postfire. The probability that dead trees would fall changed over time and varied among size classes, with smaller stems exhibiting a higher probability of falling earlier (Fig. 5). From 2014 to 2019, most pieces of deadwood remained at decomposition class 1 or class 2. Overall fuel loading in 2019 was very similar to the 2013, pre-fire level; litter (measured by Brown's transects) generally recovered to pre-fire levels, although new duff formation was still essentially zero (duff persisted in the approximately $5 \%$ of the surface that was unburned). Importantly, biomass of coarse woody debris in 2019 was almost the same as 2013 (Figs. 6, 7). Wood from large-diameter trees ( $\geq 60 \mathrm{~cm}$ diameter) comprised $57 \%$ of surface fuel in 2019 and was 75\% of snag biomass (Fig. 7).

\section{Discussion}

A notable characteristic of Sierra Nevada forests is their potential to include large-diameter trees. These trees generate high levels of large-diameter fuel in sometimes long sections (Figs. 2, 6). Furthermore, Sierra Nevada forests have a heterogeneous structure in terms of the presence of small- and large-diameter trees, snags, and deadwood at multiple scales, which is at least partly due to spatial and temporal heterogeneity in fire behavior and effects (Jeronimo et al. 2019, 2020). This fire-induced heterogeneity depends on the structural heterogeneity associated with spatial variation in large-diameter trees (Furniss et al. 2020b) and largediameter deadwood (Lutz et al. 2009a, Lutz et al. 2013, Kane et al. 2014). The formation dynamics of deadwood, in turn, inherently depend on the fire frequency and the ability of trees to reach large diameters prior to mortality. In the Abies concolor/Pinus lambertiana zone, the prevalence of large pieces of deadwood, both of those that persist through fire and post-fire inputs, reinforces the ecological significance of large-diameter trees, even beyond their death (Hyde et al. 2011, Lutz et al. 2018a).

To our knowledge, this study is the first-ever spatially explicit analysis of snag and deadwood dynamics after fire conducted at this spatial scale $(25.6 \mathrm{ha})$ and including this range of diameter classes $(1 \mathrm{~cm} \leq$ diameter < $201 \mathrm{~cm}$ ). The time trends, and, importantly, the variation around the means (Fig. 2) are important data for landscape-scale accumulation of fuel. These data could be of particular value to provide a baseline dataset to predict how other carbon dynamics and woody debris in ecosystems may respond to fire, especially if those ecosystems are experiencing higher fire frequencies due to shifts in fire regimes (Smith et al. 2016).

Variation in pre-fire forest structure and site conditions can determine accumulation of large-diameter fuel following fire (Cansler et al. 2019, Lutz et al. 2018b). In 


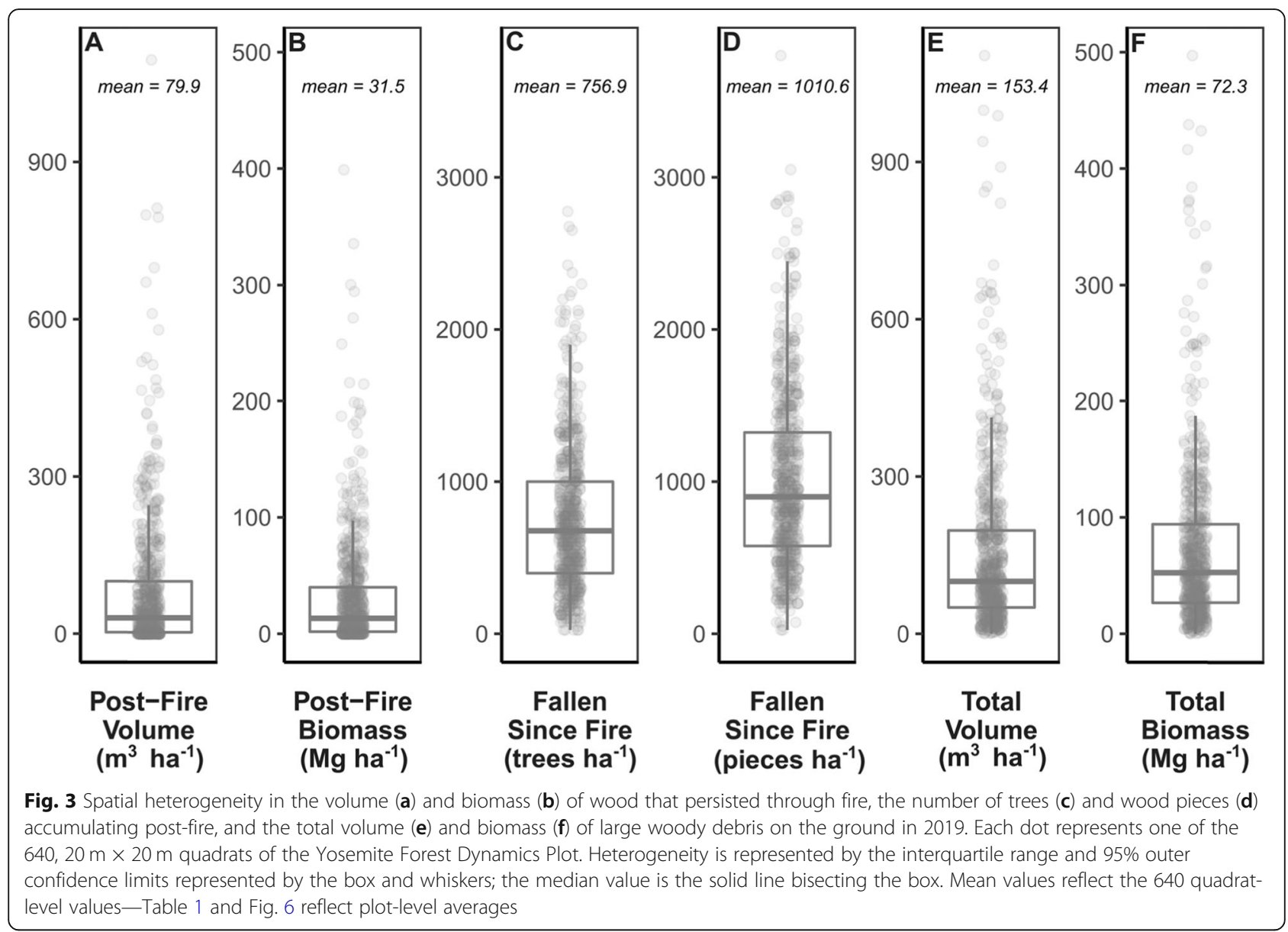

the intervals between fire, deadwood decays at various rates depending on landscape position (Privetivy et al. 2018), and directly contributes to biodiversity by providing a substrate (Taborska et al. 2015) and modifying the local environment (Vrška et al. 2015). Areas remaining unburned within fire perimeters (Kolden et al. 2015, Meddens et al. 2018), due either to low pre-fire fuel loads, low connectivity, or wet landscape positions (Kolden et al. 2012), can function as refugia for small-statured trees (Blomdahl et al. 2019a) and other elements of the biota (Roberts et al. 2008, Blomdahl et al. 2019b); such refugia can also serve as areas where fuel accumulates between fires which, in turn, impacts

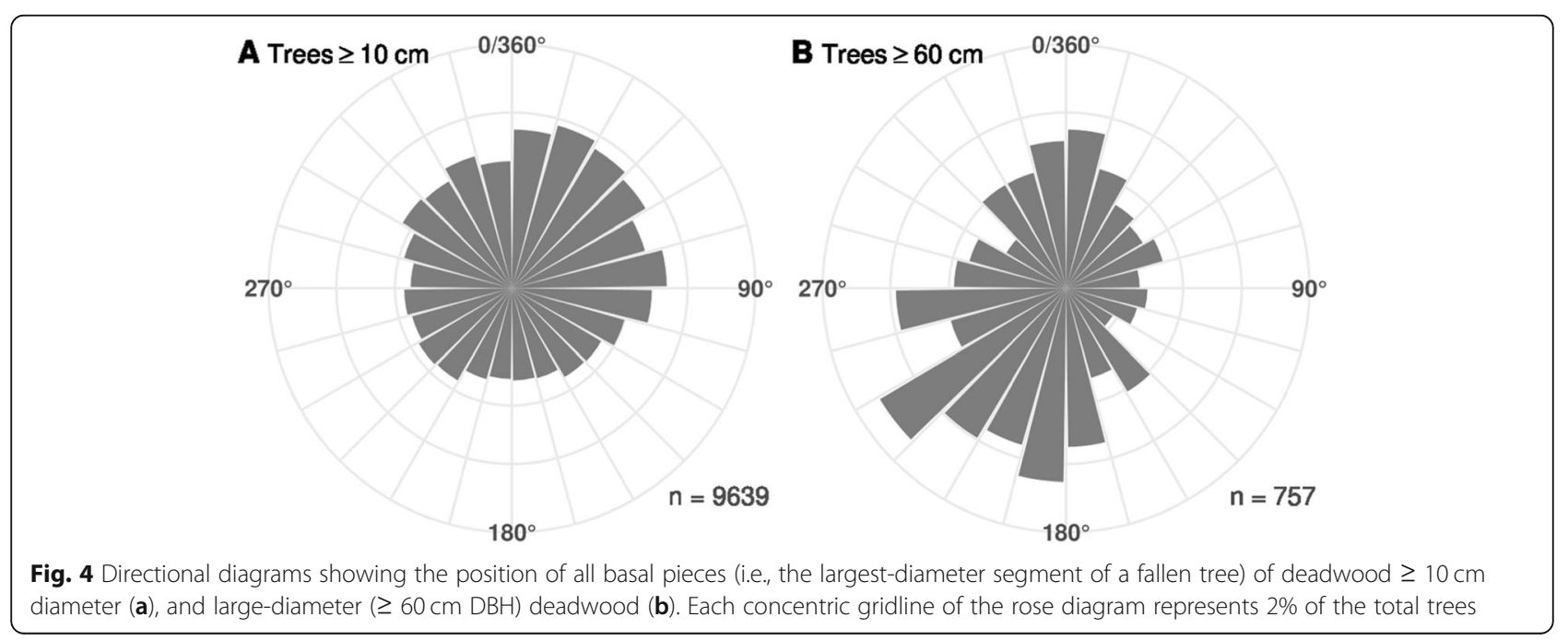




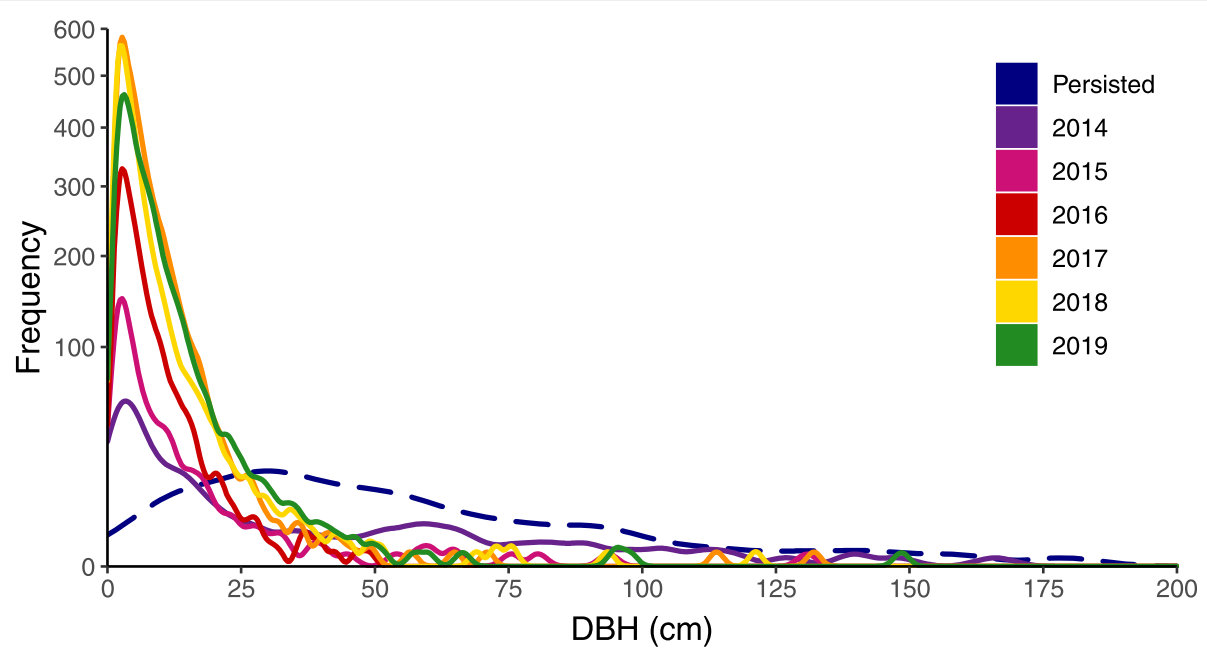

Fig. 5 Diameter distribution of each piece of fallen trees (remaining stump $<1.37 \mathrm{~m}$ high) from 2014-2019 in the Yosemite Forest Dynamics Plot, as well as the post-fire diameter distribution of those pieces that persisted through the Rim Fire. Trees $<10 \mathrm{~cm} \mathrm{DBH}$ were considered to have fallen as a single piece; wood from trees $\geq 10 \mathrm{~cm}$ DBH was mapped explicitly by piece. Colors correspond to those in Fig. 1. Curves are based on the raw diameters smoothed with a Gaussian density kernel. The square-root transformation of the $y$-axis shows the low frequency but cumulative effects of large-diameter inputs

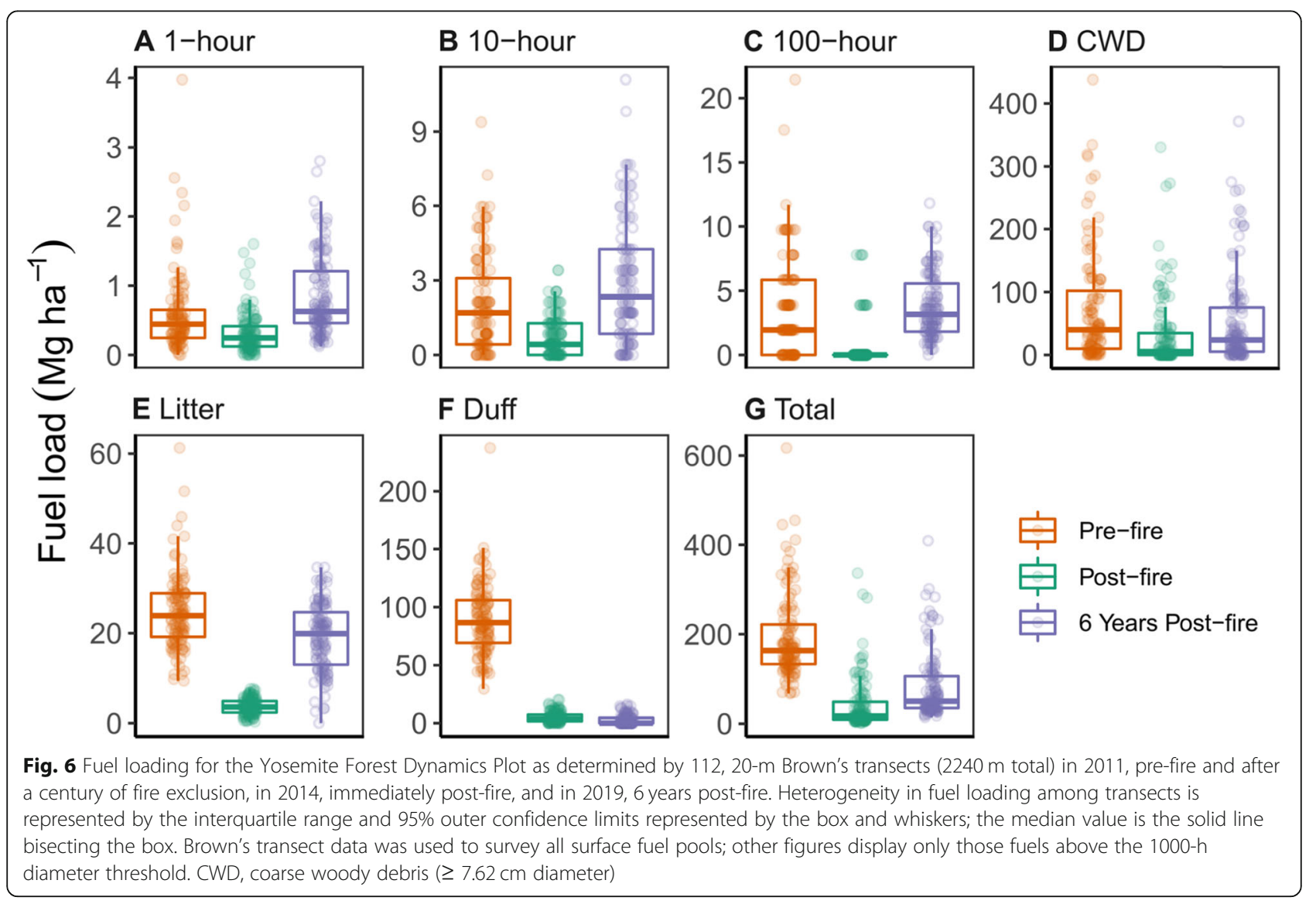




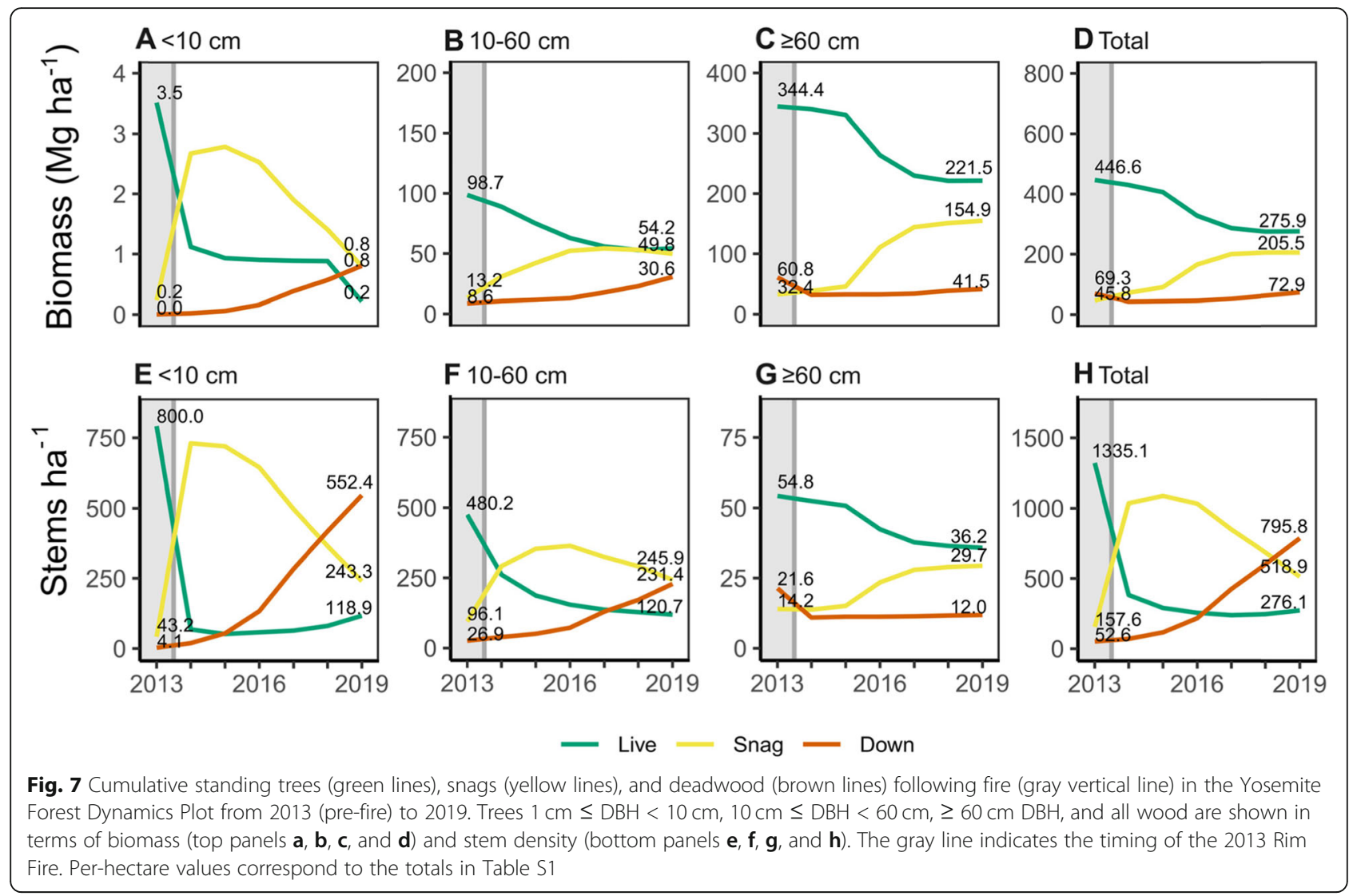

ecosystem vulnerability and future heterogeneity of fire behavior and effects (Vaillant et al. 2016, Kolden et al. 2017).

Rapid post-fire fuel accumulation, particularly from small-diameter tree mortality, suggests that repeated burns may be necessary to return historical ecological processes and to bolster resilience to future fire (Stevens et al. 2014). We show that 2013 (pre-fire) and 2019 (post-fire) surface fuels were virtually indistinguishable in total amount due to a net balance of fuels consumed during the fire and fuels accumulated post-fire, reflecting high fire-related mortality rates expected following fire exclusion (Varner et al. 2007). The exception to this was the duff layer, which had not begun to accumulate again by 2019. The Rim Fire caused widespread tree and shrub mortality, dramatically reducing ladder fuels and canopy bulk density. Although surface fuel loads in our study site have returned to pre-fire levels, the composition of fuels is distinct (more fine fuels, similar amount of deadwood, lower shrub cover, and canopy fuels [Fig. 5]). The different fuel structure that has emerged will influence the intensity of repeat burns, though it is difficult to predict the directionality of this relationship (and will depend greatly on fire weather and fuel moisture levels). Future fires will be necessary to return surface fuels to the pre-suppression levels that facilitated frequent, low-severity fire in this forest (Larson et al. 2013), but these fires may still pose a risk to the remaining live trees, particularly those in the large-diameter cohort (Lutz et al. 2018) that were damaged in the Rim Fire or to newer cohorts that have not yet developed morphological protections (Smith et al. 2017, Steady et al. 2019). Smoldering of large logs contributes to large-diameter tree mortality by creating large wounds (i.e., catfaces), causing mechanical failure in previous fire scars (Furniss et al. 2019), and scalding shallow subsurface roots (as with duff smoldering sensu Varner et al. 2009).

Broader multi-agent interactions mediated the delayed mortality processes that contributed to the rapid accumulation of large-diameter deadwood following fire (Furniss et al. 2020b). Importantly, coarse woody debris accumulated later than finer fuels due to specific mortality and fragmentation processes affecting the largest diameter class of trees (Furniss et al. 2020b), indicated by field observations including (1) saprophytic rot entering fire-killed portions of live trees, contributing eventually to structural failure; (2) windthrow or stem breakage of trees made structurally unstable by the fire itself (i.e., large cat faces, reduced heartwood); and (3) fireincreased bark beetle activity (such as by Dendroctonus valens LeConte). However, these processes often resulted in fragmented wood (i.e., branches and treetops) rather than whole snagfall and thus contributed less to the accumulation of large-diameter fuels than did rotand fire-related collapse. In future fires, the presence 
and relative abundances of biotic agents along with observed fire severity will likely determine delayed mortality rates and further coarse woody debris accumulation (i.e., Hood et al. 2018).

Understanding snag and wood dynamics is critically important for evaluating the tradeoffs and effects of possible post-fire management actions such as salvage logging or reforestation planting on a host of key concerns (Graham et al. 1994), including future wildfire potential (Johnson et al. 2020), wildlife habitat conservation and development (Schaedel et al. 2017), distribution of shrubs and forbs (Halpern and Lutz 2013), forest recruitment, forest carbon sequestration, and $\mathrm{CO}_{2}$ emissions from fire (Stenzel et al. 2019).

The study demonstrates the ecological processes that govern future fire risk; small diameter stems rapidly contribute to an increasing fuel load, whereas the larger boles (which are the focus of salvage logging) fall at a lower rate that may be delayed 1-6 years following fire. Experimental and simulation studies demonstrate short-term increases but long-term decreases in woody surface fuel loadings in salvage-logged post-fire conifer forests compared to untreated controls (McIver and Ottmar 2007, Dunn and Bailey 2015, McIver and Ottmar 2018, Johnson et al. 2020). However, a second fire or reburn can erase salvage logging treatment effects on standing and down woody fuel loadings (McIver and Ottmar 2018) and override salvage logging effects on fire risk, suggesting that in landscapes conducive to a regime of frequent surface fires, timely reintroduction of repeated fires may be the most effective restoration post-fire management strategy (Larson et al. 2013).

This study is particularly relevant to identify methods for quantifying fire-induced movement of sequestered carbon from the live tree carbon pool to the deadwood carbon pool (Stenzel et al. 2019). With the exception of surface fuels, leaves, and fine branches that are completely consumed, fire does not rapidly release much carbon from larger woody structures directly into the atmosphere (Table 1). Fire and fire-mediated biotic or physical agents can kill live trees, but it takes many years for decay microbes to cycle that carbon into atmospheric $\mathrm{CO}_{2}$ and soil carbon pools. This is particularly true regarding carbon stored in large-diameter trees, where the majority of aboveground forest carbon is found (Stephenson et al. 2014, Lutz et al. 2018). For example, 62 years after clear-cut harvest and broadcast burning, large-diameter legacy wood originating from the preharvest stand still accounted for $45 \%$ of aboveground woody detritus stocks in a long-term replicated forest development experiment (Schaedel et al. 2017). While newly created snags and fallen surface fuels will burn during future fires, any pieces that are not completely consumed will become charred, which can increase the carbon residence in these systems (DeLuca et al. 2008,
Brewer et al. 2013, Santin et al. 2015, Ward et al. 2017). The low-consumption rate and long retention times of large logs facilitates the continued conversion of biomass by soil microbes into recalcitrant forms of soil organic matter, which constitutes the largest and longest-lived carbon pool in temperate forests (Lal 2005, Averill et al. 2014), provided soil incorporation occurs faster than other removal mechanisms like erosion and repeated fires (Tinkham et al. 2016). As such, carbon stored within large-diameter trees is at least partially retained following fire-induced mortality and accumulation as coarse woody debris.

\section{Conclusions}

The consequences of a first-entry burn in areas where fire has long been excluded are starting to be understood, with broad implications for landscape and resource management. In this forest, the Rim Fire consumed $61 \%$ of the total deadwood $\geq 10 \mathrm{~cm}$ diameter existing pre-fire, but post-fire accumulation of coarse wood $\geq 10 \mathrm{~cm}$ diameter contributed $41 \mathrm{Mg} \mathrm{ha}^{-1}$, replacing the pre-fire loadings of coarse fuels within 6 years. Total pre-fire surface fuels of all classes as measured by planar transects (and after 113 years of fire exclusion) were $192 \mathrm{Mg} \mathrm{ha}^{-1}$ and 6 years post-fire total surface fuels were $83 \mathrm{Mg} \mathrm{ha}^{-1}$ (Fig. 6), a difference due primarily to the slow development of the thick duff layer that was present pre-fire. The high biomass in largediameter snags (154.9 $\mathrm{Mg} \mathrm{ha}^{-1}$; Fig. 7) suggests that these large-diameter structures will continue to contribute to surface fuels for many years. Repeated fires will be necessary to restore the pre-European settlement ecological dynamics of this forest by reducing these fuels to a level where subsequent fire will not have the potential to burn at high intensity and effect widespread large tree mortality. More broadly, these findings suggest that adequately dealing with the structural and demographic consequences of fire deficit in fire-excluded dry forests is a multi-stage process that merits further observation and experimentation.

\section{Supplementary information}

Supplementary information accompanies this paper at https://doi.org/10. 1186/s13717-020-00243-8.

\footnotetext{
Additional file 1: Table S1. Yearly totals of trees, snags, and deadwood for the Yosemite Forest Dynamics Plot including recruitment, two different categories of mortality (transitions of trees to the snag pool and transitions of trees directly to the surface deadwood pool) and snagfall (transition of a snag to the surface deadwood pool). Dead trees $\geq 1.37 \mathrm{~m}$ tall are classified as snags. Dead trees with a remaining stump height < $1.37 \mathrm{~m}$ tall are classed as deadwood. Fig. S1. Deadwood $\geq 10 \mathrm{~cm}$ diameter from 2013 and earlier that persisted through fire in the Yosemite Forest Dynamics Plot. ABCO - Abies concolor, ABMA - Abies magnifica, CADE - Calocedrus decurrens, CONU - Cornus nuttallii, PILA Pinus lambertiana, PSME - Pseudotsuga menziesii, QUKE - Quercus kelloggii, UNKN - Unknown. Fig. S2. New deadwood $\geq 10 \mathrm{~cm}$ diameter from 2014 in the Yosemite Forest Dynamics Plot. ABCO - Abies concolor, ABMA - Abies magnifica, CADE - Calocedrus decurrens, CONU - Cornus nuttallii, PILA - Pinus lambertiana, PSME - Pseudotsuga menziesii, QUKE -
} 
Quercus kelloggii, UNKN - Unknown. Fig. S3. New deadwood $\geq 10 \mathrm{~cm}$ diameter from 2015 in the Yosemite Forest Dynamics Plot. ABCO - Abies concolor, ABMA - Abies magnifica, CADE - Calocedrus decurrens, CONU Cornus nuttallii, PILA - Pinus lambertiana, PSME - Pseudotsuga menziesii, QUKE - Quercus kelloggii, UNKN - Unknown. Fig. S4. New deadwood $\geq 10 \mathrm{~cm}$ diameter from 2016 in the Yosemite Forest Dynamics Plot. ABCO - Abies concolor, ABMA - Abies magnifica, CADE - Calocedrus decurrens, CONU - Cornus nuttallii, PILA - Pinus lambertiana, PSME - Pseudotsuga menziesii, QUKE - Quercus kelloggii, UNKN - Unknown. Fig. S5. New deadwood $\geq 10 \mathrm{~cm}$ diameter from 2017 in the Yosemite Forest Dynamics Plot. ABCO - Abies concolor, ABMA - Abies magnifica, CADE - Calocedrus decurrens, CONU - Cornus nuttallii, PILA - Pinus lambertiana, PSME Pseudotsuga menziesii, QUKE - Quercus kelloggii, UNKN - Unknown. Fig. S6. New deadwood $\geq 10 \mathrm{~cm}$ diameter from 2018 in the Yosemite Forest Dynamics Plot. ABCO - Abies concolor, ABMA - Abies magnifica, CADE Calocedrus decurrens, CONU - Cornus nuttallii, PILA - Pinus lambertiana, PSME - Pseudotsuga menziesii, QUKE - Quercus kelloggii, UNKN Unknown. Fig. S7. New deadwood $\geq 10 \mathrm{~cm}$ diameter from 2019 in the Yosemite Forest Dynamics Plot. ABCO - Abies concolor, ABMA - Abies magnifica, CADE - Calocedrus decurrens, CONU - Cornus nuttallii, PILA Pinus lambertiana, PSME - Pseudotsuga menziesii, QUKE - Quercus kelloggii, UNKN - Unknown. Fig. S8. Cumulative deadwood $\geq 10 \mathrm{~cm}$ diameter in the Yosemite Forest Dynamics Plot in 2019, six years following fire. ABCO - Abies concolor, ABMA - Abies magnifica, CADE Calocedrus decurrens, CONU - Cornus nuttallii, PILA - Pinus lambertiana, PSME - Pseudotsuga menziesii, QUKE - Quercus kelloggii, UNKN Unknown. Fig. S9. Spatial variation of surface fuel biomass $(\geq 10 \mathrm{~cm}$ diameter) in the Yosemite Forest Dynamics Plot at $20 \mathrm{~m} \times 20 \mathrm{~m}$ grain. Locally high levels of biomass persisted through the 2013 Rim Fire (A), contributing $43 \%$ of total surface fuels $\geq 10 \mathrm{~cm}$ diameter present in 2019 (B).

\section{Abbreviations}

DBH: Diameter at breast height, $1.37 \mathrm{~m}$ above the pre-fire forest surface; $\mathrm{Mg}$ $\mathrm{ha}^{-1}$ : Megagrams per hectare, approximately equal to 0.45 tons per acre; YFDP: Yosemite Forest Dynamics Plot

\section{Acknowledgements}

The authors thank the field crews who gathered data, each individually acknowledged at http://yfdp.org. We thank the managers and staff of Yosemite National Park for their logistical assistance. We thank the anonymous reviewers for their time and suggestions for improvement and the Rush Creek Lodge (http://rushcreeklodge.com) for gratis WiFi access.

\section{Authors' contributions}

JAL conceived the study. JAL, CAC, and SS performed analyses. JAL, SS, TJF, SJG, MES, and AJL collected data. All authors contributed to writing and editing the manuscript. All authors read and approved the final manuscript.

\section{Funding}

Funding was received from the Utah Agricultural Experiment Station (projects 1153, 1398, and 1423 to JAL), the Joint Fire Science Program (award 16-1-04-02 to JAL and AJL), the National Park Service (Awards P14AC00122 and P14AC00197 to JAL), and the Smithsonian Institution ForestGEO. Research was performed under National Park Service research permits YOSE2013-SCI-0012, YOSE-2014-SCI-0005, YOSE-2015-SCI-0014, YOSE-2016-SCI0006, YOSE-2017-SCI-0008, YOSE-2018-SCI-0006, and YOSE-2019-SCI-0009 for study YOSE-0051.

\section{Availability of data and materials}

All data necessary to recreate analyses is available from the corresponding author.

\section{Ethics approval and consent to participate}

Not applicable

\section{Consent for publication}

Not applicable

\section{Competing interests}

The authors declare no competing interests.

\section{Author details}

${ }^{1}$ Department of Wildland Resources, S. J. and Jessie E. Quinney College of Natural Resources, Utah State University, 5230 Old Main Hill, Logan, Utah 84322-5230, USA. ${ }^{2}$ School of Environmental and Forest Sciences, University of Washington, Box 352100, Seattle, Washington 98195, USA. ${ }^{3}$ Management of Complex Systems, University of California, Merced, 5200 North Lake Road, Merced, California 95343, USA. ${ }^{4}$ Department of Forest, Rangeland, and Fire Sciences, College of Natural Resources, University of Idaho, 875 Perimeter Drive, Moscow, Idaho 83844-1133, USA. ${ }^{5}$ School of the Environment, Washington State University, Box 646410, Pullman, Washington 99164-6420, USA. ${ }^{6}$ Wilderness Institute, W. A. Franke College of Forestry and Conservation, University of Montana, 32 Campus Drive, Missoula, Montana 59812, USA.

Received: 19 May 2020 Accepted: 30 June 2020

Published online: 27 July 2020

\section{References}

Anderson-Teixeira KJ, Davies SJ, Bennett AC, Gonzalez-Akre EB, Muller-Landau HC, Wright SJ, Abu Salim K, Baltzer JL, Bassett Y, Bourg NA, Broadbent EN, Brockelman WY, Bunyavejchewin S, Burslem DFRP, Butt N, Cao M, Cardenas D, Clay K, Condit RS, Detto M, Du X, Duque A, Erikson DL, Ewango CEN, Fletcher CD, Gilbert GS, Gunatilleke N, Gunatilleke S, Hao Z, Hargrove WH, Hart TB, Hao B, He F, Hoffman FM, Howe R, Hubbell SP, Jansen PA, Jiang M, Kanzaki M, Kenfack D, Kinnaird MF, Kumar J, Larson AJ, Li Y, Li X, Liu S, Lum SKY, Lutz JA, Ma K, Maddalena D, Makana JR, Malhi Y, Marthews T, McMahon S, McShea WJ, Memiaghe H, Mi X, Mizuno T, Myers JA, Novotny V, de Oliveira AA, Orwig D, Ostertag R, den Ouden J, Parker G, Phillips R, Rahman A, Sringernyuang K, Sukumar R, Sun IF, Sungpalee W, Tan S, Thomas SC, Thomas D, Thompson J, Turner BL, Uriarte M, Valencia R, Vallejo MI, Vicentini A, Vrška T, Wang X, Weiblen G, Wolf A, Xu H, Xugao W, Yap S, Zimmerman J (2015) CTFS-ForestGEO: a worldwide network monitoring forests in an era of global change. Global Change Biology 21(2):528-549 https://doi.org/10.1111/gcb. 12712

Averill C, Turner BL, Finzi AC (2014) Mycorrhiza-mediated competition between plants and decomposers drives soil carbon storage. Nature 505(7484):543545

Barth MAF, Larson AJ, Lutz JA (2015) Use of a forest reconstruction model to assess changes to Sierra Nevada mixed-conifer forest during the fire suppression era. Forest Ecology and Management 354:104-118 https://doi. org/10.1016/j.foreco.2015.06.030

Becker KML, Lutz JA (2016) Can low-severity fire reverse overstory compositional change in montane forests of the Sierra Nevada, USA? Ecosphere 7(12): e01484 https://doi.org/10.1002/ecs2.1484

Bivand R, Keitt T, Rowlingson B (2019) rgdal: Bindings for the geospatial data abstraction library. R package version 1:4-8 https://CRAN.R-project.org/ package=rgdal

Bivand R, Rundel C (2019) rgeos: Interface to geometry engine. R package version 0.5-2. https://CRAN.R-project.org/package=rgeos

Blomdahl EM, Kolden CA, Meddens AJH, Lutz JA (2019a) The importance of small fire refugia in the central Sierra Nevada, California, USA. Forest Ecology and Management 432:1041-1052 https://doi.org/10.1016/j.foreco.2018.10.038

Blomdahl EM, Thompson CM, Kane JR, Kane VR, Churchill DJ, Moskal LM, Lutz JA (2019b) Forest structure predictive of fisher (Pekania pennanti) dens exists in recently burned forest in Yosemite, California, USA. Forest Ecology and Management 444:174-186 https://doi.org/10.1016/j.foreco.2019.04.024

Brewer NW, Smith AMS, Hatten JA, Higuera PE, Hudak AT, Ottmar RD, Tinkham WT (2013) Fuel moisture influences on fire-altered carbon in masticated fuels: an experimental study. Journal of Geophysical Research 118:30-40 https:// doi.org/10.1029/2012JG002079

Brown JK (1974) Handbook for inventorying downed woody material. USDA Forest Service General Technical Report INT-16. Ogden, Utah: USDA Forest Service, Intermountain Forest and Range Experiment Station.

Cansler CA, Swanson ME, Furniss TJ, Larson AJ, Lutz JA (2019) Fuel dynamics after reintroduced fire in an old-growth Sierra Nevada mixed-conifer forest. Fire Ecology 15:16 https://doi.org/10.1186/s42408-019-0035-y

Chojnacky DC, Heath LS, Jenkins JC (2014) Updated generalized biomass equations for North American tree species. Forestry 87:129-151 
Core Team R (2020) A language and environment for statistical computing. R Foundation for Statistical Computing, Vienna, Austria https://www.R-project. org

DeLuca TH, Aplet GH (2008) Charcoal and carbon storage in forest soils of the Rocky Mountain West. Frontiers in Ecology and the Environment 6(1):18-24 https://doi.org/10.1890/070070

Donato DC, Fontaine JB, Campbell JL, Robinson WD, Kauffman JB, Law BE (2006) Post-wildfire logging hinders regeneration and increases fire risk. Science 311(5759):352 https://doi.org/10.1126/science.1122855

Dunn CJ, Bailey JD (2015) Modeling the direct effects of salvage logging on long-term temporal fuel dynamics in dry-mixed conifer forests. Forest Ecology and Management 341:93-109 https://doi.org/10.1016/j.foreco.2015. 01.002

Fulé PZ, Cocke AE, Heinlein TA, Covington WW (2004) Effects of an intense prescribed forest fire: is it ecological restoration? Ecological Restoration 12(2): 220-230 https://doi.org/10.1111/j.1061-2971.2004.00283.x

Furniss TJ, Kane VR, Larson AJ, Lutz JA (2020a) Detecting actual tree mortality with satellite-derived spectral indices and estimating landscape-level uncertainty. Remote Sensing of Environment 237:111497 https://doi.org/10. 1016/j.rse.2019.111497

Furniss TJ, Kane VR, Larson AJ, Lutz JA (2020b) Wildfire and drought moderate the spatial elements of tree mortality. Ecosphere.

Furniss TJ, Larson AJ, Kane VR, Lutz JA (2019) Multi-scale assessment of post-fire tree mortality models. International Journal of Wildland Fire 28(1):46-61 https://doi.org/10.1071/WF18031

Graham RT, Harvey AE, Jurgensen MF, Jain TB, Tonn JR, Page-Dumroese DS (1994) Managing coarse woody debris in forests of the Rocky Mountains. USDA Forest Service Research Paper INT-RP-477

Grayson LM, Cluck DR, Hood SM (2019) Persistence of fire-killed conifer snags in California, USA. Fire Ecology 15:1 https://doi.org/10.1186/s42408-018-0007-7

Grayson LM, Progar RA, Hood SM (2017) Predicting post-fire tree mortality for 14 conifers in the Pacific Northwest, USA: model evaluation, development, and thresholds. Forest Ecology and Management 399:213-226 https://doi.org/10. 1016/j.foreco.2017.05.038

Halpern CB, Lutz JA (2013) Canopy closure exerts weak controls on understory dynamics: a 30-year study of overstory-understory interactions. Ecological Monographs 83(2):221-237 https://doi.org/10.1890/12-1696.1

Harmon ME, Woodall CW, Fasth B, Sexton J (2008) Woody detritus density and density reduction factors for tree species in the United States: a synthesis. In: General Technical Report NRS-29. Research Station, USDA Forest Service, Newton Square, PA, Northern https://doi.org/10.2737/NRS-GTR-29

Harris L, Taylor AH (2015) Topography, fuels, and fire exclusion drive fire severity of the Rim Fire in an old-growth mixed-conifer forest, Yosemite National Park, USA. Ecosystems 18:1192-1208 https://doi.org/10.1007/s10021-0159890-9

Hessburg PF, Churchill DJ, Larson AJ, Haugo RD, Miller C, Spies TA, North MP, Povak NA, Belote RT, Singleton PH, Gaines WL, Keane RE, Aplet GH, Stephens SL, Morgan P, Bisson PA, Rieman BE, Salter RB, Reeves GH (2015) Restoring fire-prone Inland Pacific landscapes: seven core principles. Landscape Ecology 30:1805-1835 https://doi.org/10.1007/s10980-015-0218-0

Hood SM, Varner JM, van Mantgem P, Cansler CA (2018) Fire and tree death: understanding and improving modeling of fire-induced tree mortality. Environmental Research Letters 13(11):113004

Hyde JC, Smith AMS, Ottmar RD, Alvarado EC, Morgan P (2011) The combustion of sound and rotten coarse woody debris: a review. International Journal of Wildland Fire 20:163-174 https://doi.org/10.1071/WF09113

Janík D, Král K, Adam D, Vrška T, Lutz JA (2018) Smithsonian ForestGEO dead wood census protocol. In: Utah State University Digital Commons Paper 76. Utah, Logan https://doi.org/10.26078/vcdr-y089

Jeronimo SMA, Kane VR, Churchill DJ, Lutz JA, North MP, Asner GP, Franklin JF (2019) Forest structure and pattern vary by climate and landform across active-fire landscapes in the montane Sierra Nevada. Forest Ecology and Management 427:70-86 https://doi.org/10.1016/j.foreco.2019.01.033

Jeronimo SMA, Lutz JA, Kane VR, Larson AJ, Franklin JF (2020) Burn weather and three-dimensional fuel structure determine post-fire tree mortality. Landscape Ecology 35:859-878 https://doi.org/10.1007/s10980-020-00983-0

Johnson MC, Kennedy MC, Harrison SC, Churchill D, Pass J, Fischer PW (2020) Effects of post-fire management on dead woody fuel dynamics and stand structure in a severely burned mixed-conifer forest, in northeastern Washington State, USA. Forest Ecology and Management 470:118190 https:// doi.org/10.1016/j.foreco.2020.118190
Johnstone JF, Allen CD, Franklin JF, Frelich LE, Harvey BJ, Higuera PE, Mack MC, Meentemeyer RK, Metz MR, Perry GLW, Schoennagel T, Turner MG (2016) Changing disturbance regimes, ecological memory, and forest resilience. Frontiers in Ecology and the Environment 14:369-378 https://doi.org/10. 1002/fee.1311

Kane VR, Bartl-Geller BN, North MP, Kane JT, Lydersen JM, Jeronimo SMA, Collins BM, Moskal LM (2019) First-entry wildfires can create opening and tree clump patterns characteristic of resilient forests. Forest Ecology and Management 454:117659 https://doi.org/10.1016/j.foreco. 2019.117659

Kane VR, Cansler CA, Povak NA, Kane JT, McGaughey RJ, Lutz JA, Churchill DJ, North MP (2015) Mixed severity fire effects within the Rim fire: relative importance of local climate, fire weather, topography, and forest structure. Forest Ecology and Management 358:62-79 https://doi.org/10.1016/j.foreco.2015.09.001

Kane VR, North M, Lutz JA, Churchill D, Roberts SL, Smith DF, McGaughey RJ, Kane JT, Brooks ML (2014) Assessing fire-mediated change to forest spatial structure using a fusion of Landsat and airborne LiDAR data in Yosemite National Park. Remote Sensing of Environment 151:89-101 https://doi.org/10. 1016/j.rse.2013.07.041

Kolden CA, Abatzoglou JT, Lutz JA, Cansler CA, Kane JT, van Wagtendonk JW, Key $\mathrm{CH}$ (2015) Climate contributors to forest mosaics: ecological persistence following wildfire. Northwest Science 89(3):219-238 https://doi.org/10.3955/ 046.089.0305

Kolden CA, Bleeker TM, Smith AMS, Poulos HM, Camp AE (2017) Fire effects on historical wildfire refugia in contemporary wildfires. Forests 8:400

Kolden CA, Lutz JA, Key CH, Kane JT, van Wagtendonk JW (2012) Mapped versus actual burned area within wildfire perimeters: characterizing the unburned. Forest Ecology and Management 286:38-47 https://doi.org/10.1016/j.foreco. 2012.08.020

Lal R (2005) Forest soils and carbon sequestration. Forest Ecology and Management 220:242-258 https://doi.org/10.1016/j.foreco.2005.08.015

Larson AJ, Belote RT, Cansler CA, Parks S, Dietz MS (2013) Latent resilience in ponderosa pine forest: effects of resumed frequent fire. Ecological Applications 23(6):1243-1249 https://doi.org/10.1890/13-0066.1

Levine CR, Cogbill CV, Collins BM, Larson AJ, Lutz JA, North MP, Restaino CM, Safford HD, Stephens SL, Battles JJ (2017) Evaluating a new method for reconstructing forest conditions from General Land Office survey records. Ecological Applications 27(5):1498-1513 https://doi.org/10.1002/ eap.1543

Levine CR, Cogbill CV, Collins BM, Larson AJ, Lutz JA, North MP, Restaino CM, Safford HD, Stephens SL, Battles JJ (2019) Estimating historical forest density from land-survey data: a response to Baker and Williams (2018). Ecological Applications 29(8):e01968 https://doi.org/10.1002/eap.1968

Lutz JA (2015) The evolution of long-term data for forestry: large temperate research plots in an era of global change. Northwest Science 89(3):255-269 https://doi.org/10.3955/046.089.0306

Lutz JA, Furniss TJ, Germain SJ, Becker KML, Blomdahl EM, Jeronimo SMA, Cansler CA, Freund JA, Swanson ME, Larson AJ (2017) Shrub communities, spatial patterns, and shrub-mediated tree mortality following reintroduced fire in Yosemite National Park, California, USA. Fire Ecology 13(1):104-126 https:// doi.org/10.4996/fireecology.1301104

Lutz JA, Furniss TJ, Johnson DJ, Davies SJ, Allen D, Alonso A, Anderson-Teixeira K, Andrade A, Baltzer J, Becker KML, Blomdahl EM, Bourg NA, Bunyavejchewin S, Burslem DFRP, Cansler CA, Cao K, Cao M, Cárdenas D, Chang L-W, Chao K-J, Chao W-C, Chiang J-M, Chu C, Chuyong BB, Clay K, Condit R, Cordell S, Dattaraja HS, Duque A, Ewango CEN, Fisher GA, Fletcher C, Freund JA, Giardina C, Germain SJ, Gilbert GS, Hao Z, Hart T, Hau BCH, He F, Hector A, Howe RW, Hsieh C-F, Hu Y-H, Hubbell SP, Inman-Narahari FM, Itoh A, Janík D, Kassim AR, Kenfack D, Korte L, Král K, Larson AJ, Li Y-D, Lin Y, Liu S, Lum S, Ma K, Makana J-R, Malhi Y, McMahon SM, McShea WJ, Memiaghe HR, Mi X, Morecroft M, Musili PM, Myers JA, Novotny V, de Oliveira A, Ong P, Orwig DA, Ostertag R, Parker GG, Patankar R, Phillips RP, Reynolds G, Sack L, Song G-ZM, Su S-H, Sukumar R, Sun I-F, Suresh HS, Swanson ME, Tan S, Thomas DW, Thompson J, Uriarte M, Valencia R, Vicentini A, Vrška T, Wang X, Weiblen GD, Wolf A, Wu S-H, Xu H, Yamakura T, Yap S, Zimmerman JK (2018a) Global importance of large-diameter trees. Global Ecology and Biogeography 27(7): 849-864 https://doi.org/10.1111/geb.12747

Lutz JA, Halpern CB (2006) Tree mortality during early forest development: a long-term study of rates, causes, and consequences. Ecological Monographs 76(2):257-275 https://doi.org/10.1890/00129615(2006)076[0257:TMDEFD]2.0.CO;2 
Lutz JA, Larson AJ, Freund JA, Swanson ME, Bible KJ (2013) The importance of large-diameter trees to forest structural heterogeneity. PLoS ONE 8(12): e82784 http://dx.plos.org/10.1371/journal.pone.0082784

Lutz JA, Larson AJ, Swanson ME (2018b) Advancing fire science with large fores plots and a long-term multidisciplinary approach. Fire 1(1):5 https://doi.org/ 10.3390/fire1010005

Lutz JA, Larson AJ, Swanson ME, Freund JA (2012) Ecological importance of large-diameter trees in a temperate mixed-conifer forest. PLOS ONE 7(5): e36131 http://dx.plos.org/10.1371/journal.pone.0036131

Lutz JA, van Wagtendonk JW, Franklin JF (2009a) Twentieth-century decline of largediameter trees in Yosemite National Park, California, USA. Forest Ecology and Management 257(11):2296-2307 https://doi.org/10.1016/j.foreco.2009.03.009

Lutz JA, van Wagtendonk JW, Thode AE, Miller JD, Franklin JF (2009b) Climate, lightning ignitions, and fire severity in Yosemite National Park, California, USA. International Journal of Wildland Fire 18(7):765-774 https://doi.org/10. 1071/WF08117

Lydersen JM, North MP, Collins BM (2014) Severity of an uncharacteristically large wildfire, the Rim Fire, in forests with relatively restored frequent fire regimes. Forest Ecology and Management 328:326-334 https://doi.org/10.1016/j. foreco.2014.06.005

Mclver JD, Ottmar R (2007) Fuel mass and stand structure after post-fire logging of a severely burned ponderosa pine forest in northeastern Oregon. Forest Ecology and Management 238:268-279 https://doi.org/10.1016/j.foreco.2006.10.021

Mclver JD, Ottmar R (2018) Fuel mass and stand structure 13 years after logging of a severely burned ponderosa pine forest in northeastern Oregon, U.S.A. Forest Ecology and Management 424:505-518 https://doi.org/10.1016/j. foreco.2018.04.047

Meddens AJH, Kolden CA, Lutz JA, Smith AMS, Cansler CA, Abatzoglou J, Meigs G, Downing W, Krawchuk M (2018) Fire refugia: what are they and why do they matter for global change? BioScience 68(12):944-954 https://doi.org/10. 1002/ecs2.2029

Miller C, Urban DL (2000) Modeling the effects of fire management alternatives on Sierra Nevada mixed-conifer forests. Ecological Applications 10(1):8594 https://doi.org/10.1890/1051-0761(2000)010[0085:MTEOFM]2.0.CO;2

Odion DC, Hanson CT (2006) Fire severity in conifer forests of the Sierra Nevada, California. Ecosystems 9:1177-1189 https://doi.org/10.1007/s10021-003-0134-z

Passovoy MD, Fulé PZ (2006) Snag and woody debris dynamics following severe wildfires in northern Arizona ponderosa pine forests. Forest Ecology and Management 223(1-3):237-246 https://doi.org/10.1016/j.foreco.2005.11.016

Pebesma EJ (2018) Simple features for R: standardized support for vector data. The R Journal 10(1):439-446 https://doi.org/10.32614/RJ-2018-009

Pebesma EJ, Bivand RS (2005) Classes and methods for spatial data in R. R News 5(2) https://cran.r-project.org/doc/Rnews/

Povak N, Churchill D, Cansler CA, Hessburg PF, Kane VR, Kane JT, Lutz JA, Larson AJ (2020) Wildfire severity and post-fire salvage harvest effects on long-term forest regeneration. Ecosphere. https://doi.org/10.1002/ecs2.3199

Privetivy T, Adam D, Vrška T (2018) Decay dynamics of Abies alba and Picea abies deadwood in relation to environmental conditions. Forest Ecology and Management 427:250-259 https://doi.org/10.1016/j.foreco.2018.06.008

Roberts SL, van Wagtendonk JW, Kelt DA, Miles AK, Lutz JA (2008) Modeling the effects of fire severity and spatial complexity on small mammals in Yosemite National Park, California. Fire Ecology 4(2):83-104 https://doi.org/10.4996/ fireecology.040208

Santin C, Doerr SH, Preston CM, Gonzalez-Rodriguez G (2015) Pyrogenic organic matter production from wildfires: a missing sink in the global carbon cycle. Global Change Biology 21(4):1621-1633 https://doi.org/10.1111/gcb.12800

Schaedel MS, Larson AJ, Weisbrod CJ, Keane RE (2017) Density-dependent woody detritus accumulation in an even-aged, single-species forest. Canadian Journal of Forest Research 47:1215-1211 https://doi.org/10.1139/cjfr-2017-0129

Scholl AE, Taylor AH (2010) Fire regimes, forest change, and self-organization in an old-growth mixed-conifer forest, Yosemite National Park, USA. Ecological Applications 20(2):362-380 https://doi.org/10.1890/08-2324.1

Smith AMS, Kolden CA, Paveglio TB, Cochrane MA, Bowman D, Moritz MA, Kliskey AD, Alessa L, Hudak AT, Hoffman CM, Lutz JA, Queen LP, Goetz SJ, Higuera PE, Boschetti L, Flannigan M, Yedinak KM, Watts AC, Strand EK, van Wagtendonk JW, Anderson JW, Stocks BJ, Abatzoglou JT (2016) The science of firescapes: achieving fire resilient communities. BioScience 66(2):130-146 https://doi.org/10.1093/biosci/biv182

Smith AMS, Talhelm AF, Johnson DM, Sparks AM, Kolden CA, Yedinak KM, Apostol KG, Tinkham WT, Abatzoglou JT, Lutz JA, Pregitzer KS, Adams HD, Kremens RL (2017) Impacts of fire radiative energy density doses on Pinus contorta and Larix occidentalis seedling physiology and mortality. International Journal of Wildland Fire 26(1):82-94 https://doi.org/10.1071/WF16077

Stalling C, Keane RE, Relzlaff M (2017) Surface fuel changes after severe disturbances in northern Rocky Mountain ecosystems. Forest Ecology and Management 400:38-47 https://doi.org/10.1016/j.foreco.2017.05.020

Stavros EN, Tane Z, Kane VR, Veraverbeke S, McGaughey RJ, Lutz JA, Ramirez C, Schimel D (2016) Unprecedented remote sensing data over the King and Rim megafires in the Sierra Nevada Mountains of California. Ecology 97(11): 3244 https://doi.org/10.1002/ecy.1577

Steady WD, Feltrin RP, Johnson DM, Sparks AM, Kolden CA, Talhelm AF, Lutz JA, Boschetti L, Hudak AT, Nelson AS, Smith AMS (2019) The survival of Pinus ponderosa saplings to increasing levels of fire intensity and impacts on postfire growth. Fire 2:23 https://doi.org/10.3390/fire2020023

Stenzel JE, Bartowitz KJ, Hartman MD, Lutz JA, Kolden CA, Smith AMS, Swanson ME, Larson AJ, Parton WJ, Hudiburg TW (2019) Fixing a snag in carbon emissions estimates from wildfires. Global Change Biology 25(11):3985-3994 https://doi.org/10.1111/gcb.14716

Stephens SL (2004) Fuel loads, snag abundance, and snag recruitment in an unmanaged Jeffrey pine-mixed conifer forest in Northwestern Mexico. Forest Ecology and Management, 199(1):103-113 https://doi.org/0.1016/j.foreco.2 004.04.017

Stephens SL, Moghaddas JJ (2005) Fuel treatment effects on snags and coarse woody debris in a Sierra Nevada mixed conifer forest. Forest Ecology and Management 214(1-3):53-64 https://doi.org/10.1016/j.foreco.2005.03.055

Stephenson NL, Das AJ, Condit R, Russo SE, Baker PJ, Beckman NG, Coomes DA, Lines ER, Morris WK, Rüger N, Alvarez E (2014) Rate of tree carbon accumulation increases continuously with tree size. Nature 507(7490):90-93

Stevens JT, Safford HD, Latimer AM (2014) Wildfire-contingent effects of fuel treatments can promote ecological resilience in seasonally dry conifer forests. Canadian Journal of Forest Research 44(8):843-854 https://doi.org/10.1139/cjfr-2013-0460

Taborska M, Privetivy T, Vrška T, Odor P (2015) Bryophytes associated with two tree species and different stages of decay in a natural fir-beech mixed forest in the Czech Republic. Preslia 87:387-401 http://www.preslia.cz/P154Taborska.pdf

Thaxton JM, Platt WJ (2006) Small-scale fuel variation alters fire intensity and shrub abundance in a pine savanna. Ecology 87:1331-1337 https://doi.org/ 10.1890/0012-9658(2006)87[1331:SFVAFI]2.0.CO;2

Tinkham WT, Smith AMS, Higuera PE, Hatten JA, Brewer NB, Doerr SH (2016) Replacing time with space: using laboratory fires to explore the effects of repeated burning on black carbon degradation. International Journal of Wildland Fire 25:242-248 https://doi.org/10.1071/WF15131

USFS (2012) Clearing after the devil's windstorm - cutting blowdown trees from trails, Inyo National Forest, California. USFS Recreation \& Natural Resources Briefing Paper. October 2012. Downloaded 15 April 2020 from: https://www. fs.usda.gov/Internet/FSE_DOCUMENTS/stelprdb5370647.pdf

Vaillant NM, Kolden CA, Smith AMS (2016) Assessing landscape vulnerability to wildfire in the United States. Current Forestry Reports 2(3):201-213 https:// doi.org/10.1007/s40725-016-0040-1

van Wagtendonk JW, Moore PE, Yee JL, Lutz JA (2020) The distribution of woody species in relation to climate and fire in Yosemite National Park, California, USA. Fire Ecology

Vanderwel MC, Malcolm JR, Smith SM (2006) An integrated model for snag and downed woody debris decay class transitions. Forest Ecology and Management 234(1-3):48-59 https://doi.org/10.1016/j.foreco.2006.06.020

Varner JM, Heirs JK, Ottmar RD, Godron DR, Putz FE, Wade DD (2007) Overstory tree mortality resulting from reintroducing fire to long-unburned longleaf pine forests: the importance of duff moisture. Canadian Journal of Forest Research 37:1349-1358 https://doi.org/10.1139/X06-315

Varner MJ, Putz FE, O'Brien JJ, Kevin Hiers J, Mitchell RJ, Gordon DR (2009) Postfire tree stress and growth following smoldering duff fires. Forest Ecology and Management 258:2467-2474 https://doi.org/10.1139/X06-315

Vrška T, Privetivy T, Janík D, Unar P, Samonil P, Král K (2015) Deadwood residence time in alluvial hardwood temperate forests - a key aspect of biodiversity conservation. Forest Ecology and Management 357:33-41 https:/doi.org/10.1016/j.foreco.2015.08.006

Ward A, Cansler CA, Larson AJ (2017) Black carbon on coarse woody debris in once- and twice-burned mixed-conifer forest. Fire Ecology 13(2):143-147 https://doi.org/10.4996/fireecology.130288796

\section{Publisher's Note}

Springer Nature remains neutral with regard to jurisdictional claims in published maps and institutional affiliations. 